Institute for Applied Agroecology, Rostock ${ }^{1}$ and Research Institute for Biology of Farm Animals, Dummerstorf ${ }^{2}$. Germany

HEINZ FALKENBERG', ULLA RENNE ${ }^{2}$ and MARTINA LANGHAMMER ${ }^{2}$

\title{
Biochemical characterisation of blood metabolic substances in mice after long-term selection on growth traits
}

\author{
Dedicated to Professor Dr. Dr. H. H. Sambraus on the occasion of his $65^{\text {th }}$ birthday
}

\begin{abstract}
Summary
A biochemical characterisation of blood was done in laboratory mouse lines originating from a heterogeneous outbred strain Fzt:DU which were selected for high body weight at 6 weeks of age (DU-6), for high total protein amount in the carcass (DU-6P) and for an index combining body weight and treadmill performance (DU-6+TP) over 54 generations, respectively. The level of the following enzymes and substrates were compared to the unselected control group (Fzt:DU): alanine aminotransferase (ALAT), aspartate aminotransferase (ASAT), lactate dehydrogenase (LDH), creatine kinase (CK), $\gamma$-glutamyl-transpeptidase (GGTP), alkaline phosphatase (AP), total cholesterol with its components LDL+VLDL- and HDL-cholesterol, triglyceride (Trig.), creatinine (Crea.), lactate (Lac.) and glucose (Gluc.). Concentration of some metabolic substances differed significantly in relation to the specific selection character. It is concluded, that selection indirectly diversified physiological state in the tested long-term selection lines in mice.
\end{abstract}

Key Words: mice, long-term selection, growth, selection response, blood traits, enzymes, substrates

\section{Zusammenfassung}

Titel der Arbeit: Biochemische Charakterisierung von Stoffwechselkennwerten von Labormăusen nach Langzeitselektion auf Wachstum

Labormäuse des Auszuchtstammes Fzt:DU wurden uber 54 Generationen auf verschiedene Wachstumsmerkmale selektiert. Die Tiere der Linie DU-6 wurden auf hohes Körpergewicht am 42. Lebenstag, die der Linie DU-6P auf hohe Proteinmenge im Schlachtkörper am 42 Lebenstag und die der Linie DU-6+LB auf einen Index aus hohem Korpergewicht und hoher Laufleistung am 42. Lebenstag gezllchtet. Die Wirkung der Selektion auf ausgewăhlte biochemische Kennwerte im Blutplasma wurde ermittelt. Folgende Enzyme und Substrate wurden an den Selektionslinien untersucht und mit dem Gehalt im Plasma der Kontrolltiere aus der Fzt:DU-Linie verglichen: Alaninaminotransferase (ALAT), Aspartataminotransferase (ASAT), Lactatdehydrogenase (LDH), Creatinkinase (CK), $\gamma$-Glutamyl-Transpeptidase (GGTP), Alkalische Phosphatase (AP), Gesamtcholesterin mit seinen Komponenten LDL+VLDL- und HDL-Cholesterin, Triglyceride (Trig.), Kreatinin (Crea.), Lactat (Lac.) und Glucose (Gluc.). Die Konzentration einiger Stoffwechselprodukte unterschied sich signifikant in Abhăngigkeit von der Selektionsrichtung. Das weist darauf hin, dass durch die Leistungsselektion der physiologische Status von Tieren beeinflußt wird.

Schlüsselwörter: Maus, Langzeitselektion, Wachstum, Blutplasmamerkmale, Enzyme, Substrate

\section{Introduction}

Selection experiments with the aim to predict the selection response in farm animal breeding can most efficiently and appropriately be done using a convenient laboratory animal. The mouse is a useful laboratory animal for such purposes because of its short generation interval and low unit running costs. Several selection experiments for body 
weight or body weight gain in mice have been described with a distinct direct (reviews: e.g. ROBERTS, 1979; EISEN, 1974, 1980; McCARTHY, 1982; BÜNGER, 1990; FALCONER, 1989, 1992; CABALLERO, 1992) or indirect response in growth performance traits (reviews: e.g.; McCARTHY, 1982; STEPHENSON and MALIK, 1984; BÜNGER, 1990 in body composition).

The aim of following article is to investigate the effect of growth selection for three different selection traits on biochemical blood parameters, which characterise the physiological status of the selected mouse lines, compared with a control. Using blood plasma 6 enzymes and 7 substrates were determined in selected and control animals.

\section{Material and Method}

All data were obtained in the Mouse Laboratory in Dummerstorf and based on the outbred strain (Fzt:DU), which has been obtained in 1969/1970 by systematic crossbreeding of 4 inbred and 4 outbred lines. All experimental animals were kept in a semi-barrier system. Feed and water were available ad lib.

In 1975 a growth selection experiment was started. Three selection lines were created by dividing full sibs into these lines. In all 3 lines litters/ full sib groups were selected, with a mean selection quote of about $50 \%$, for the sum of the performance of 2 test males. These test males were randomly chosen and marked at 10 days. After evaluation of the performance of these test males at 42 days they were eliminated.

First line (DU-6) was selected for body weight at 42 days. A second line (DU-6P) was selected for total protein amount. Carcasses without coat, head, digestive tract and legs were analysed by a standard chemical method (Kjeldahl-procedure) for total Nitrogen (N). The protein amount was estimated as $\mathrm{N} \times 6.25$. The selection trait in the third line (DU-6+TP) was an index combining body weight and a trait for endurance fitness (covered way in a treadmill: treadmill performance). Simultaneously a control line (Fzt:DU) was kept. This line was randomly selected with a population size of 200

Table 1

View about mouse lines and selection response (Übersicht aber die Langzeitselektionslinien und Selektionserfolge)

\begin{tabular}{|c|c|c|c|c|c|}
\hline $\begin{array}{l}\text { Line } \\
\text { generation } \\
\text { males start/end }\end{array}$ & Selection trait & $\begin{array}{l}\text { Selection } \\
\text { start }\end{array}$ & $\rightarrow$ & end & $\%$ \\
\hline $\begin{array}{l}\text { DU-6 } \\
54 \\
70 / 52 \\
\end{array}$ & Body weight & $29.8 \mathrm{~g}$ & $\rightarrow$ & $52.9 \mathrm{~g}$ & 77 \\
\hline $\begin{array}{l}\text { DU-6P } \\
54 \\
69 / 58 \\
\end{array}$ & Protein amount & $2.95 \mathrm{~g}$ & $\rightarrow$ & $4.83 \mathrm{~g}$ & 64 \\
\hline $\begin{array}{l}\text { DU-6+TP } \\
54 \\
72 / 56 \\
\end{array}$ & $\begin{array}{l}\text { Index : } \\
\text { Body weight and } \\
\text { Treadmill performance }\end{array}$ & $\begin{array}{l}30.2 \mathrm{~g} \\
1248 \mathrm{~m} \\
\end{array}$ & $\begin{array}{l}\rightarrow \\
\rightarrow\end{array}$ & $\begin{array}{l}44.2 \mathrm{~g} \\
3297 \mathrm{~m} \\
\end{array}$ & $\begin{array}{r}46 \\
164 \\
\end{array}$ \\
\hline $\begin{array}{l}\text { Fzt:DU } \\
98 \text { or } 100 \\
69\end{array}$ & $\begin{array}{l}\text { Control } \\
\text { Body weight } \\
\text { Protein amount } \\
\text { Treadmill performance }\end{array}$ & & & $\begin{array}{c}28.4 \mathrm{~g} \\
2.9 \mathrm{~g} \\
1549 \mathrm{~m}\end{array}$ & \\
\hline
\end{tabular}


pairs, to get a preferably insignificant increase of inbreeding. In all selection lines the litter size was standardised to 8 (gen. 0-15) or 9 (gen. 16-70). Litters smaller than 7 pups were discarded. There were in every generation 80 matings at a ratio 1:1 at $63 \pm 3$ days. Full sib mating was avoided.

The obtained results in the genetic improvement of the different selection objectives were published by SCHÜLER (1985), BÜNGER (1990), RENNE et al. (1995, 1997) and BÜNGER et al. (1990, 1993, 1994, 1998).

Following selection response in selection traits at $42^{\text {nd }}$ day was reached after 54 generations: DU-6: $23.1 \mathrm{~g}$, DU-6P: $1.88 \mathrm{~g}$, DU-6+TP: $14 \mathrm{~g}$ and $2049 \mathrm{~m}$, respectively (Table 1).

The blood was collected at slaughtering on day 70 and frozen after centrifugation for getting blood plasma. The analysed characters were determined photometrically by standard methods at $37^{\circ} \mathrm{C}$. A photometer (LP 400) of the firm LANGE, Berlin was used. The list of the tested six enzymes and seven substances is shown in Table 2.

Table 2

Determined metabolic substances in mice blood plasma (Untersuchte Blutplasmakennwerte bei Măusen)

\begin{tabular}{|c|c|c|}
\hline Traits & Abbreviation & Unit \\
\hline Aspartate aminotransferase & ASAT (AST, GOT) & nkat/l \\
\hline Alanine aminotransferase & $\operatorname{ALAT}(\mathrm{ALT}, \mathrm{GPT})$ & nkat/l \\
\hline Lactate dehydrogenase & LDH & nkat/1 \\
\hline Creatine kinase & CK & nkat/1 \\
\hline Alkaline phosphatase & AP & nkat/l \\
\hline$\gamma$-Glutamyl-transpeptidase & GGTP $(\gamma-G T)$ & nkat/l \\
\hline Total cholesterol & Chol. & $\mathrm{mmol} / \mathrm{l}$ \\
\hline High density lipoproteins cholesterol & HDL-Chol. & $\mathrm{mmol} / \mathrm{l}$ \\
\hline $\begin{array}{l}\text { Low density + very low density lipoproteins } \\
\text { cholesterol }\end{array}$ & LDL+VLDL-Chol. & $\mathrm{mmol} / \mathrm{l}$ \\
\hline Triglyceride & Trig. & $\mathrm{mmol} / \mathrm{l}$ \\
\hline Glucose & Gluc. & $\mathrm{mmol} / \mathrm{l}$ \\
\hline Lactate & Lac. & $\mathrm{mmol} / \mathrm{l}$ \\
\hline Creatinine & Crea. & $\mu \mathrm{mol} / \mathrm{l}$ \\
\hline
\end{tabular}

For the examination of blood traits 146 mice in line DU-6, 122 mice in line DU-6P and 127 mice in line DU-6+TP with about the same sex ratio were included from generation 54. 185 animals of the outbred mouse strain Fzt:DU were used as a control line.

Population genetic analysis were carried out using SAS program package. The effects of sex and line were tested with variance analysis.

\section{Results}

In the regarded mouse lines the direct selection for body weight or protein amount effected in considerable changes in growth, body size and body composition (Table 1). The concentration of enzymes and substrates in the blood plasma differed in the same way between the selected growth lines and the unselected control line. 
Figure 1 shows the level of the enzyme activities of ASAT, ALAT and LDH in the three growth lines compared to the control line. The level of aspartate aminotransferase is significantly lower in the three growth lines versus control animals. Within the growth lines the distinctly lowest ASAT-concentration was observed in DU-6. Against that the ALAT- concentrations did not differ significantly between the growth lines and the control line and among each other.
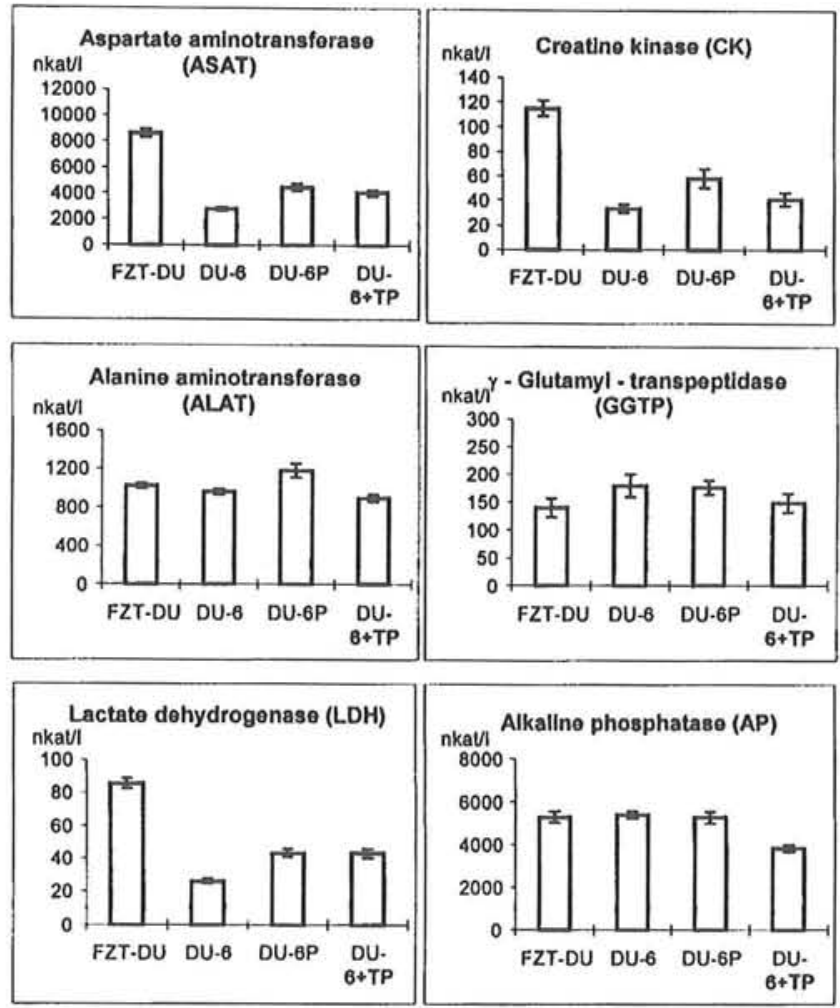

Fig. 1: Enzyme activities in the blood plasma of mouse lines (Enzymaktivitäten im Blutplasma der Langzeitselektionslinien)

The tendencial higher ALAT-level in line DU-6P seems to correlate with the increased body protein amount. In the selected lines the activity of the enzyme LDH amounted only percentages of $30.6 \%$ (DU-6), $50.9 \%$ (DU-6P) and $50.7 \%$ (DU-6+TP) versus the control line. That indicates a significant decrease in all growth lines in the LDH level.

Further blood plasma enzyme activities are demonstrated in Figure 1. The trait creatinine kinase (CK) as a criteria for fitness yielded the lowest level in line DU-6 (33.2 nkat/l) compared to the control line with $114.8 \mathrm{nkat} / \mathrm{l}$. In line DU-6P (58.2 nkat/l) and line DU-6+TP (41.2 nkat/l) the CK- level was significantly smaller than in the control line. Animals of the line DU-6P showed again higher CK-levels compared to both other growth lines. 
The enzyme $\gamma$-glutamyl-transpeptidase (GGTP) is responsible for the absorption of amino acids into the cells and reflects the protein extension or even the whole growth of the animals. With 179.5 nkat/l (DU-6) and 176.6 nkat/l (DU-6P) are the detected GGTP- levels up to $28.5 \%$ significantly higher than in the control line. Combining selection for growth traits with locomotory activity in an index as happened in line DU-6+TP, the detected GGTP concentration (148.9 nkat/l) was at nearly the same level as in the control line.

The alkaline phosphatase (AP) as a typical enzyme for the skeleton growth did not differ between the mouse lines DU-6, DU-6P and the control line. Against that a distinctly lower AP-concentration was found in the combined selection line DU-6+TP. Cholesterol as an essential component for somatic cells will be transported with the help of special lipoproteins in the blood to all target organs. The subgroups HDLcholesterol and LDL+VLDL-cholesterol are especially important for arteriosclerosis. They are described separately in Figure 2.
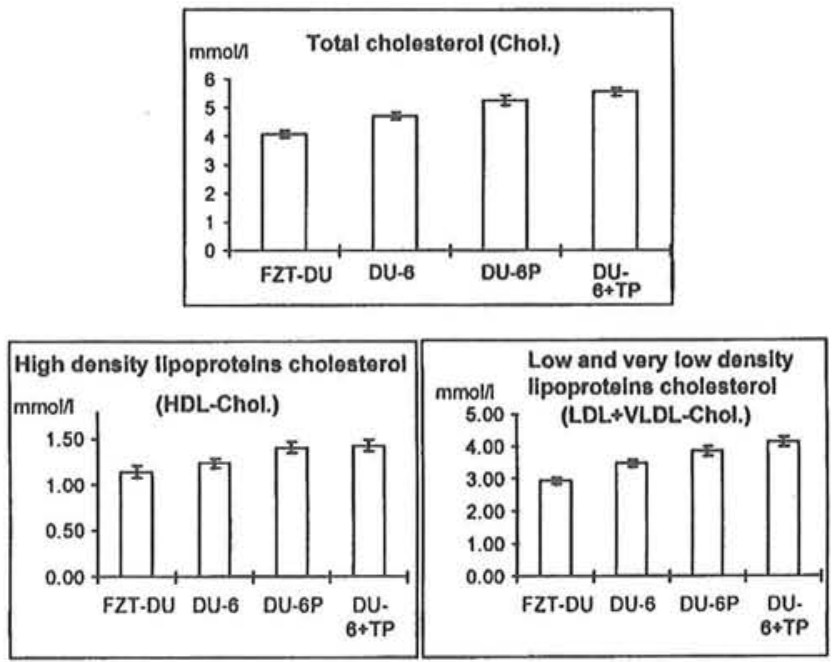

Fig. 2: Cholesterol concentration in blood of mouse lines (Cholesterinkonzentration im Blutplasma der Langzeitselektionslinien)

As a result of long-term selection, the level of total cholesterol ( $p \leq 0.05$ ), HDLcholesterol and LDL+VLDL-cholesterol $(p \leq 0.05)$ was increased on average in the selected growth lines compared to the control line. All the traits showed the highest concentration in the combined selection line DU-6+TP. The relationship between the components of cholesterol could be assess more meaningful in a graphical description (Figure 3).

The line specific presentation regards the course of cholesterol concentration rising from the smallest cholesterol concentration to the maximum of total cholesterol in the animals. Whereas the portion of HDL-cholesterol in relation to the total cholesterol was nearly constant, the proportion of LDL+VLDL-cholesterol ascends with increasing total cholesterol in the blood plasma in all the included mouse lines. 


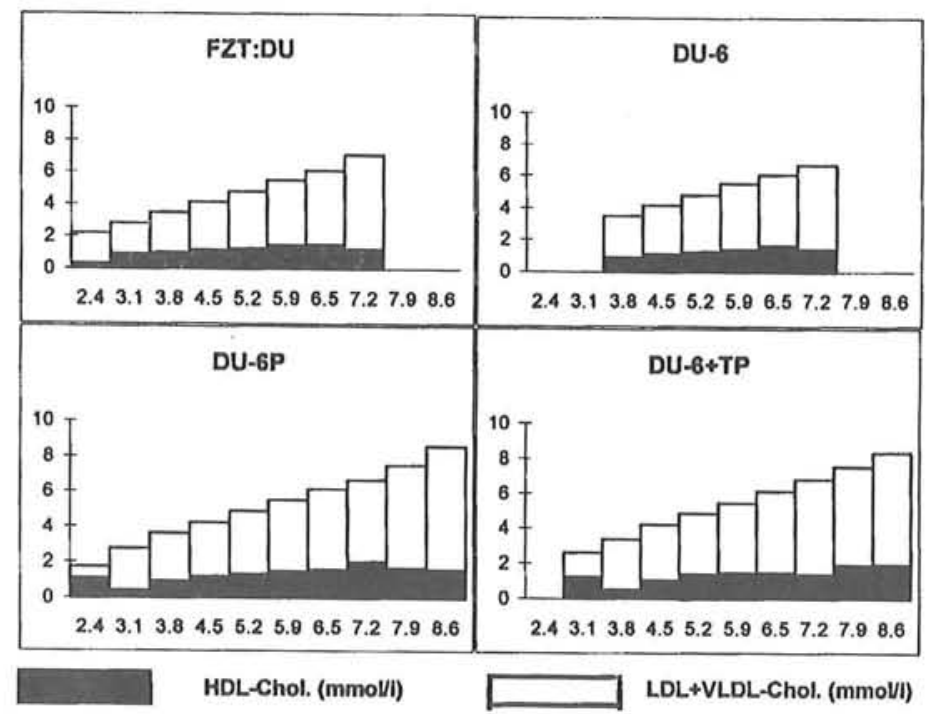

Fig. 3: Variation of cholesterol metabolites in mouse lines (Entwicklung der Cholesterinmetaboliten in den Langzeitselektionslinien)
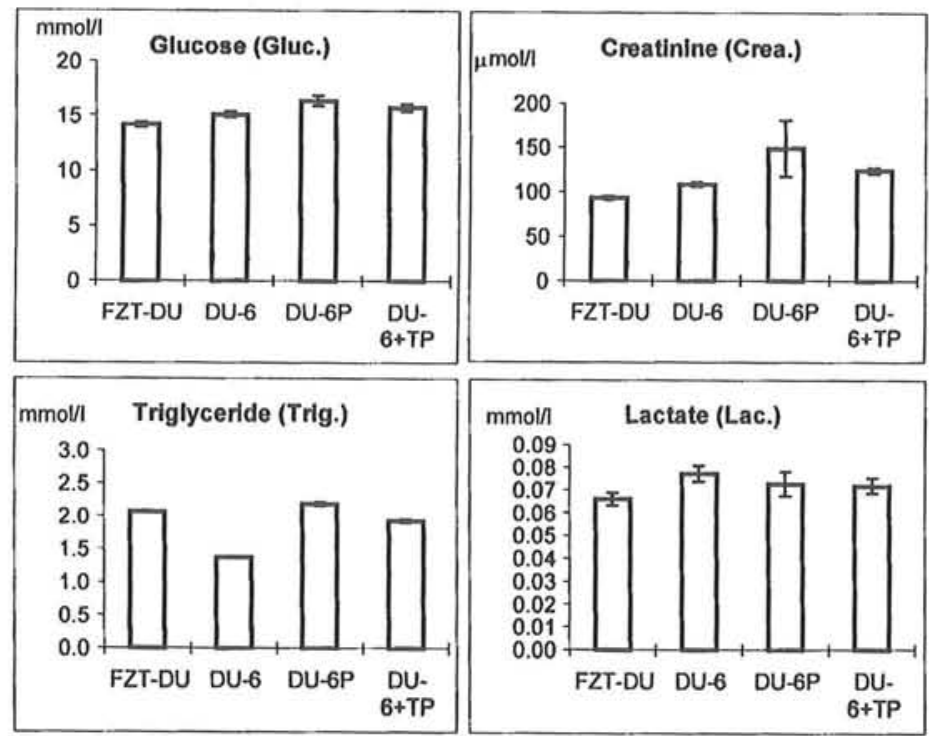

Fig. 4: Substrates in the blood plasma of mouse lines (Blutplasmasubstrate in den Langzeitselektionslinien)

Furthermore, the level of glucose, triglycerides, creatinine and lactate were determined in the blood plasma (Figure 4). The glucose concentration was not different between the mouse lines. In tendency the control animals had the lowest glucose concentration. 
In accordance to that the creatinine concentrations (Crea.) did not differently develop. The highest Crea. but with contemporaneously greatest variability for that trait was found in line DU-6P (148.9 mmol/l). The concentration of the triglycerides (Trig.) did not react in accordance to the selection aims because the control line, DU-6P and DU6+TP show nearly the same level. Only the animals in line Du-6 had a lower concentration in the Trig. Nearly the same ratio between the growth lines were exposed for the trait lactate in the blood plasma (DU-6: $0.077 \mathrm{mmol} / \mathrm{l}$, DU-6P: $0.073 \mathrm{mmol} / \mathrm{l}$, DU-6+TP: $0.072 \mathrm{mmol} / \mathrm{l})$. However, the lactate concentration differed significantly between the long-term selected mouse lines and the control line.

\section{Discussion}

Growth and all with the growth performance interrelated synthesis in the body are both quantitatively and qualitatively connected with the energy metabolism processes. On the other hand the fat metabolism in turn is closely linked with the energy supply and storage. Fat metabolism plays an important role to compensate for stress situations which establish strong loads and need a rapidly adaptation. Laboratory mice often are used as a model for investigations of the energy and fat metabolism in animals. A comprehensive review of growth control gene in mice was given by EFSTRATIADIS (1998). He differentiates between a group of 20 to 25 genes which are directly included in the expression of growth processes belonging to the growth hormone (GH-) insulin-like-growth-factor (IGF)- path way and a further group of 50 genes which are not directly responsible for growth but could inhibit growth functions. Long term selection for high body weight leads to a reinforced fat gain and an increased fat deposition in the body (FOWLER, 1958; HAYES and McCARTHY, 1976; EISEN et al., 1977; ROBERTS, 1979).

In the here described animal material already after eleven selection generations in the mouse line DU-6 were shown significantly higher levels in the traits body weight, fat gain, fat content, FSS- activity in the fat tissue, glucose-6-phosphatdehydrogenase and for utilisation of glucose in the triglyceride synthesis, respectively. Simultaneous selection both for body weight and treadmill performance in line DU-6+TP resulted in increased body weight, higher protein and fat amount as well as a better running activity without essential changes in body composition compared to the control line (ROSCHLAU and REMUS, 1980). That reminds on a genetic affected correlation between biochemical and physiological and phenotypic performance traits on the other side which would be induced through directed selection.

REHFELDT et al. (1989) and REHFELDT and BÜNGER (1990) observed in selection line DU-6 a higher muscle fibre size with gained body weight and an increased percentage of the white muscle fibre type. That was connected with a considerably higher anaerobe metabolism in the muscle tissue. Fibre type composition (percentage of white fibres) was not affected by selection. The results suggested that it may be possible to improve growth by selecting for muscle traits.

In male mice of more than 50 generations growth selected lines DU-6, DU-6P and DU$6+\mathrm{TP}$ energy balances were measured by means of indirect calorimetry through carbon 
and nitrogen balance. The DU-6 mice realised significantly higher daily metabolizable energy intakes and energy gains than DU-6P and the control. No differences between the selected lines were observed in thermoregulatory heat production. Differences in metabolizable energy between DU-6 and DU-6P at $22^{\circ} \mathrm{C}$ mainly due to differences in physical activity (KLEIN et al., 1999).

Results from generations 78-80 showed that DU-6 mice synthesised and deposited more protein and less fat per unit metabolic body weight than DU-6 mice (SCHADEREIT et al., 1997, 1998). Selection for high body protein amount the higher protein deposition in the carcass was due to an improved efficiency of nitrogen utilisation, a somewhat higher whole body protein synthesis combined with a slightly lower protein breakdown rate. If not combined with endurance fitness, selection for body weight resulted in an increase of body fat. Cellular structure of skeletal muscle was markedly changed by selection. The correlated selection response of skeletal muscle structure clearly differed in relation to the selection trait and was consistent with difference in body composition, protein metabolism and endurance fitness. Plasma IGF-I levels were higher in selected lines than in control; it seems to be a significant determinant in realisation of growth selection response.

BÜNGER et al. (1990) ascertained after more than 40 generations that selection for high body weight (DU-6) and protein deposition (DU-6P) had a significantly adverse effect on endurance fitness. These results in DU-6P and DU-6 were confirmed in subsequent investigations after 70 and 82 generations, respectively (RENNE et al., 1995).

A biochemical characterisation of blood metabolic substances in mice influenced by long-term selection for growth or body weight traits compared with an untreated control for such a lot of generations is not noted. Otherwise FALKENBERG et al. (1999) found partial significant differences in selected pig breeds with extremely divergent breeding aims for enzymes and substrates in the blood plasma.

In the actual study it was observed that the blood plasma level of the enzymes ASAT, $\mathrm{LDH}$ and $\mathrm{CK}$ in the three long-term selected mouse lines was significantly lower compared to the unselected control line. These three enzymes characterise the loading capacity of animals especially regarding the diseases of the liver and heart muscle as well as the permeability disturbances of the cell membranes (LÖFFLER et al., 1990). The lower enzyme level in the selection lines indicated a physiological stability exceeding the animals of the control line. Selection for growth traits decreased the enzyme activity even then if a combined index selection with body weight and locomotory activity (DU-6+TP) was accomplished. Against that the only selection for high locomotory activity was accompanied with increased enzyme levels in a longterm selected mouse line (FALKENBERG et al., 1997). Within the growth lines it is to notice that the increased protein amount in DU-6P were combined with significant higher CK activities. Direct selection for growth appears to promote genes which are responsible for a certain stolidity as a behavioural characteristic to support high growth and protein gain performances.

GGTP is described as an enzyme what will regulate the absorption of amino acids from the body fluids to the cells. Because of the high growth intensity it was to expect that 
particularly mice of the lines DU-6 and DU-6P would show an increased GGTPconcentration in the blood plasma. However, the detected slightly higher differences in GGTP did not reflect the true distances in comparison to the control line.

Cholesterol is an essential component for cell membranes and hormones as well as for energy metabolic processes. Because of its considerable hydrophobisity cholesterol is joined together with phospholipids and apoproteins to built up lipoproteins in the blood circulation. In dependence on the density of these complexes they were distributed in very low density lipoproteins cholesterol (VLDL-Chol.), low density lipoproteins cholesterol (LDL-Chol.) and high density lipoproteins cholesterol (HDL-Chol.). The component HDL-Chol. is associated with the protection of vascular membranes and with energy carrier systems in the blood. The homoeostasy of the cholesterol in the systems of cells, organs and blood components allows to use the blood concentration for evaluation (ELSTNER, 1990; KLEBER and SCHLEE, 1992). Extensive investigations in pigs, rabbits and in mice showed a great breed specific variation in the traits total cholesterol, VLDL+LDL- and HDL-Chol. (FALKENBERG et al., 1999). Selection strategies for an increase or a decrease of blood cholesterol concentration lead to distinctly varying Chol. levels (POND et al., 1992, 1997). Analogous it appears in long-term selected mouse lines, that directed genetic selection will effect the Chol. level and the Chol. subgroups depending on the specific mouse lines and selection directions. As a result of intensive growth processes DU-6, DU-6P, DU-6+TP showed significantly higher levels of total cholesterol compared to the control line Fzt:DU. However, the relationship between the various components of cholesterol did not differ between the different selection aims. Only the variation-width of the Chol. levels in the blood plasma was noticeable.

The blood glucose level in the organism is limited by insulin and its opponent glycogen as well as adrenaline, glucocorticoids, STH and thyracine and is regulated by key enzymes. A higher consumption an increased supply of glucose is characteristic under stress (KLEBER and SCHLEE, 1992). Mice of different growth lines and such which were selected for a high locomotor activity showed higher blood glucose levels compared to the control and mice lines which were long-term selected for fertility (FALKENBERG et al., 1997). Here the more intensive energy turnover in the growth lines is connected with a tendencial higher blood glucose level but not with differences in the Trig. concentration.

Creatinine arises as a metabolism product if creatininephosphat is transformed into kinetic energy of the muscle. Beside kidney insufficiency muscle diseases and damages of muscle cell-walls will increase the level of Crea. concentration in the blood plasma. Lower values are to be find under the condition of diabetes mellitus or during pregnancy. In long-term selected mouse lines for growth could be shown that the Crea. concentration exceeded the level of the control. Between the growth lines the creatinine concentrations did not differently develop. The highest Crea. but with contemporaneously greatest variability for that trait was found in line DU-6P (148.9 $\mathrm{mmol} / \mathrm{l}$, $+62 \%$ compared to Fzt:DU). In this connection KLEBER and SCHLEE (1992) reminded the effect of muscle mass inducing a higher levels of creatinine. Although in line DU-6 the body weight is much more higher than in DU-6P, the Crea. 
concentration was lower but it could be founded on the higher fat tissue percentage in the body. In pigs with a increased muscle meat percentage significantly higher Crea. levels were found compared to a pig breed with more fat (FALKENBERG et al., 1999).

In the investigated mouse lines the concentration of some metabolic substances differed significantly in relation to the specific selection direction of growth. It is concluded, that selection indirectly diversified physiological state in the tested longterm selection lines in mice.

\section{References}

BÜNGER, L.; HERRENDÖRFER, G.; RENNE, U.:

Results of long term selection for growth traits in laboratory mice. Proc. $4^{\text {th }}$ World Congress on Genetics Applied to Livestock Production, Edinburgh, 1990, 324

BÜNGER, L.; HERRENDÖRFER, G.:

Analysis of a long-term selection experiment with an exponential model. J. Anim. Breed. Genet., 110 (1993), 1-13

BÜNGER, L.; RENNE, U.; DIETL, G.:

60 generations selection for an index combining high body weight and high stress resistance in laboratory mice. $45^{\text {th }}$ World Congress on Genetics Applied to Livestock Production, Guelph, Canada, 1994

BÜNGER, L.; RENNE, U.; DIETL, G.; KUHLA, S.:

Long-term selection for protein amount over 70 generations in mice. Genet.Res., 72 (1998), 93-109

CABALLERO, A.;. HILL, W.G.: Use of inbreeding in large populations. $43^{\text {rd }}$ Annual Meeting of the EAAP, Madrid, 1992

EFSTRATIADIS, A.: Genetics of mouse growth. Int. J. Dev. Biol., 42 (1998), 955-976

EISEN, E.J.:

The laboratory mouse as a mammalian model for the genetics of growth. $1^{\text {th }}$ World Congress Applied Genetics, Madrid, (1974), 467-492

EISEN, E.J.:

Conclusions from long-term selection experiments with mice. Z. Tierzlichtg. Zuchtungsbiol., 97 (1980), 305-319

EISEN, E.J.; BAKKER, H.; NAGAI,J.:

Body composition and energetic efficiency in two lines of mice selected for rapid growth rate and their F1 crosses. Theor. Appl. Genet., 49 (1977), 21-34

ELSTNER, E.F.:

Der Sauerstoff. Wissenschaftsverlag, Mannheim, Wien, Zürich, 1990

FALKENBERG, H.; KUHN, G.; HARTUNG, M.; LANGHAMMER, M.; WOLF, C.:

Verlauf von biochemischen Kennwerten im Blut von Schweinen mit unterschiedlicher Fettansatzleistung. Arch. Tierz., Dummerstorf 42 (1999), 149-159

FALKENBERG, H.; RENNE, U.; LANGHAMMER, M.; WYTRWAT, E.: Effects of long-term selection on variation of blood metabolic substances in different mouse lines. $48^{\text {th }}$ Annual Meeting of the EAAP, 25.-28.August 1997, Wien

FALCONER, D.S.:

Early Selection Experiments. Ann.Rev.Genetics, 26 (1992), 1-14

FALCONER, D.S.: Introduction to Quantitative Genetics, Longman Group Ltd., 1989. 438 p.

FOWLER, R.E.:

The growth and carcass composition of strains of mice selected for large and small body size. J. Agric. Sci., 51 (1958), 137-148

HAYES, J.F.; MCCARTHY, J.C.:

The effects of selection at different ages for high and low body weight on the pattern of fat deposition in mice. Genet.Res.Camb., 27 (1976), 380-433 
KLEBER, H.-P.; SCHLEE, D.:

Biochemie II - Spezielle und angewandte Biochemie. Verlag G. Fischer, Jena, 2. Auflage, 1992

KLEIN, M.; SCHADEREIT, R.; SCHOLZE, H.; RENNE. U.:

Studies on energy metabolism in lines of mice selected for different growth parameters. J. Anim. Physiol. Anim. Nutr., 81 (1999), 75-89

LÖFFLER, G.; PETRIDES, E.; WEISS, L.:

McCARTHY, J.C.: Physiologische Chemie. Springer Verlag, Berlin, 4. Aufl., 1990

The laboratory mouse as a model for animal breeding: A review of selection for increased body weight and litter size. Proc. $2^{\text {nd }}$ World Congress Genetics Applied to Livestock Production, Madrid, 1982

POND, W.G.; INSULL, W.; MERSMANN, H.J.; WONG, W.W.; HARRIS, K.B.; CROSS, H.R.; SMITH, E.O.; HEATH, J.P.; KÖMÖVES, L.G.:

Effect of dietary fat and cholesterol level in growing pig selected for three generations for high or low serum cholesterol at age 56 days. J. Anim. Sci., 70 (1992), 2462

REHFELDT, C.; BÜNGER, L.; DIETL, G.; FIEDLER, I.; WEGNER, J.:

On the heritability of muscle structure traits and their genetic relationships with growth and fitness in laboratory mice. Arch. Tierz., Berlin 31 (1988), 185-195

REHFELDT, C.; BÜNGER, L.; DIETL, G.; ENDER, K.:

Zur Selektionswulrdigkeit von Merkmalen der Muskelstruktur - Modellversuch mit Labormäusen. J. Anim .Breed. Genet., 106 (1989), 208-216

REHFELDT, C.; BÜNGER, L.:

Auswirkungen einer Langzeitselektion von Labormäusen auf Merkmale des Muskelwachstums und der Muskelstruktur. Arch. Tierz., Dummerstorf 33 (1990), 507-516

RENNE, U.; BƯNGER, L.; KUHLA, S.:

Long-term selection for protein amount in mice with special consideration of a selection limit. $46^{\text {th }}$ Annual Meeting of the EAAP, Prag, 4.-7.Sept. 1995

RENNE, U.; SUMPF, D.; HERRENDÖRFER, G.:

Endurance fitness in a complete diallel cross among long-term selected mouse lines. Arch. Tierz., Dummerstorf 40 (1997), 483-490

ROBERTS, R.C.:

Side effects of selection for growth in laboratory animals. Livestock Prod. Sci., 6 (1979), 93-104

ROSCHLAU, D.; REMUS, N.:

Untersuchungen zum Fettstoffwechsel wachstumsselektierter Labormäuse. Akademie der Landwirtschaftswissenschaften der DDR, Berlin, Diss., 1980

SCHADEREIT, R.; KLEIN, M.; SOUFFRANT, W.B.; KRAWIELITZKI, K.; RENNE. U.:

Protein metabolism in mice selected for high carcass protein content or high body weight. J. Anim. Physiol. Anim. Nutr., 78 (1997), 105-118

SCHADEREIT, R.; REHFELDT, C.; KRAWIELITZKI, K.; KLEIN, M.; KANITZ, E.; KUHLA. S.:

Protein turnover, body composition, muscle characteristics and blood hormones in response to different direction of growth selection in mice. J. Anim. Feed Sci., 7 (1998), 333-352

SCHÜLER, L.:

Der Măuseauszuchtstamm Fzt:DU und seine Anwendung als Modell in der Tierzuchtforschung. Arch. Tierz., Berlin 28 (1985), 357-363

STEPHENSON, S.K.; MALIK, R.C.:

Energy partitioning and growth in mice selected for high and low body weight. Genet. Res, 43 (1984), 323-337

Received: 1999-03-16

Accepted: $2000-05-09$

Authors' addresses

Dr. habil. HEINZ FALKENBERG

Institute for Applied Agroecology

Justus-v.-Liebig-Weg 8

Dr. ULLA RENNE, Dr. MARTINA LANGHAMMER

Research Institute for the Biology of Farm Animals

D-18059 Rostock / Germany

Wilhelm-Stahl-Allee 2

D-18196 Dummerstorf/ Germany

E-Mail: renne@fbn-dummerstorf.de 


\section{Buchbesprechung}

\section{Handbuch Schweinekrankheiten}

KARL OTTO EICH, ULRICH SCHMIDT unter Mitarbeit von MARTEN DE JONG

271 Seiten, 155 farbige Abbildungen, 25 Tabellen, 9 Schaubilder, Landwirtschaftsverlag GmbH, MunsterHiltrup in der Verlagsunion Agrar, 1998, ISBN 3-7843-2937-3, 68,00 DM

Die Autoren wollen mit dieser 2. Auflage, die in vølliger Neubearbeitung vorliegt, vordergrundig die Aufklărung und Information der mit der Schweineproduktion befaßten Landwirte uber die wichtigsten und hăufigsten Erkrankungen beim Schwein erreichen. Es soll nicht den Tierarzt ersetzen, aber es soll dem Schweinehalter besser ermöglichen vorbeugende Maßnahmen einzuleiten oder Krankheiten so fruh wie moglich zu erkennen, vor allem aber sein Management auf krankheitsbegunstigende und leistungsmindernde Faktoren hin zu uberprufen. Mit diesem Anliegen einer betont anwendungsorientierten und nutzerfreundlichen Gestaltung unterscheidet sich dieses Buch von vielen Buchtiteln zu dieser Problematik.

Im allgemeinen Teil werden u.a. mehrere Krankheiten beeinflussende Faktoren, die Vorbeuge, Tier- und Bestandskontrolle, allgemeine Gesichtspunkte der Krankheitsdiagnose und Behandlung dargestellt. Den erheblich umfangreicheren und klar gegliederten Hauptteil des Buches bildet der spezielle Teil. Die in das Buch aufgenommenen, uberwiegend nach den einzelnen Organsystemen gegliederten, wichtigsten Krankheiten werden praxisrelevant besprochen. Beginnend mit den fieberhaften Allgemeinerkrankungen folgen die Erkrankungen der Haut, des Bewegungsapparates, des Blutes, Fruchtbarkeitsstorungen, die Erkrankungen des Gesăuges, der Harnorgane, der Atmungsorgane, der Verdauungsorgane, die Wurmerkrankungen und die Erkrankungen des Zentralnervensystems. Den Abschluß bildet die Beschreibung der wichtigsten, möglichen Vergiftungen. Alle Krankheiten sind nach einem einheitlichen Grundschema dargestellt, aus welchem Ursachen, Vorkommen, Krankheitserscheinung und -verlauf, möglicherweise auch ăhnliche Krankheitserscheinungen, Nachweis, Vorbeuge und Behandlung zu ersehen sind.

Die den neuesten Wissensstand einschließende, sich auf wesentliche, gut verstăndliche Texte beschränkende Aussage wird durch eine Vielzahl von sehr guten Farbfotos, Tabellen und Schaubildern wirkungsvoll unterstützt und erfullt in bester Weise das mit dieser Buchherausgabe gewollte Anliegen der Autoren.

Dieses Buch wendet sich an alle Berufsgruppen, die mit der Schweineproduktion befaßt sind. Vor allem wendet es sich an den praktischen Schweinehalter und den Auszubildenden. Aber auch an in der Beratung tătige Fachkräfte sowie Tierärzte und es ist diesem großen Nutzerkreis uneingeschränkt zu empfehlen. 